\title{
Using Mobile Educational Apps to Foster Work and Play in Learning: A Systematic Review
}

\author{
https://doi.org/10.3991/ijim.v14i18.16619 \\ Azham Hussain $\left.{ }^{(}\right)$ \\ Universiti Utara Malaysia, Sintok, Malaysia \\ azham. huumegmail.com \\ Emmanuel O.C. Mkpojiogu \\ Universiti Utara Malaysia, Sintok, Malaysia \\ Veritas University, Abuja, Nigeria \\ Elizabeth Tolulope Babalola \\ Veritas University, Abuja, Nigeria
}

\begin{abstract}
The paper examined the use of mobile educational applications to foster work and play in learning. Three research questions were asked to guide the study. Fifty (50) articles pertaining to the use of mobile educational applications in classrooms were downloaded. Out of all these papers, thirty-five (35) relevant articles were selected for review after which twenty-five (25) were carefully read and searched so as to capture the required information for the analysis. The outcome of the review indicated that there are lots of mobile educational apps that can be used by educators to foster work and play in classroom teaching and learning thereby making the teaching and learning become mobile and attractive. This means that teachers make use of apps, internet and computers to teach in classroom, which makes teaching and learning more interactive, collaborative and replaces the conventional chalkboards. The study applied systematic literature methodology in order to achieve the goal of the research. The research outcome showed that some educators have not yet embraced the use of mobile educational apps for teaching and learning in classrooms especially in third world countries. It was recommended that teachers, curriculum planners, policy makers, administrators and caregivers should be provided with knowledge on the new trend of mobile learning and its importance to the education sector.
\end{abstract}

Keywords-Classroom, mobile educational applications, teaching and learning.

\section{$1 \quad$ Introduction}

The teachers' role is to encourage and awaken learners to work and play, to find words and ways to express their ideas and develop the intellectual capabilities, improve the cognitive processes of learners, thereby creating a learning environment 
with the use of proper methodology and approaches in passing on knowledge (Dosunmu, 2011). Fredrick Froesel, a German teacher, was the first to recognize the use of play and work method in educating and teaching children in order to make teaching more concrete, real, attractive, interesting, practical and meaningful. Therefore, it is necessary that a good and resourceful teacher adopt different ways to foster work and play in the classroom in order to facilitate learning, teaching and retention of knowledge in both in and out-of-school scenarios. John Dewey, Piaget and Vygotsky all believed that children learn and develop through the incorporation of work and play in classroom setting. Throughout history, technology has played a vital role in enhancing educational realization and these has viewed over time in this way. Interestingly, Thomas Edison in 1913 projected that within 10 years, in schools, film would substitute books. Though Edison's forecast did not happen exactly as predicted, his perception has persisted in the minds of teachers, educators, instructors and policymakers (Blackwell, 2014). In view of these, mobile educational applications are growing quickly and faster making the whole world become mobile and bringing about new innovation (Blackwell, 2014). A clear example of such innovation is the use of mobile educational apps in classrooms which have fashioned the need for a novel form of learning termed mobile learning (or M-learning) (Mehdipour \& Zerehkafi, 2013). Nowadays mobile phones are not only communication devices, but also portable and private pieces of technological equipment which can be used creatively in different areas (Mehdipour \& Zerehkafi, 2013). Lots of work has being done in order to establish the benefits and usefulness of different applications and new apps were created to help in the area of fostering play and work in classroom setting. These new applications continue to proliferate and their access is made easier through the increased usage of mobile devices such as smart phones, tablet computers and the availability of Wi-Fi and cloud-based computing (Zhang \& Liao, 2015). This paper is geared to review systematically various relevant journal articles, conference proceedings and literatures pertaining to the benefits of using mobile educational applications in order to help teachers and students learn better and support faster ways to make learning more experiential. Also, the paper looked at some of the challenges facing the use of mobile educational apps in classroom, having the third world countries in mind. With the result of this research, more researchers will delve into looking at challenges raised and how it can affect students' academic performance and look into possible solutions.

It is rather unfortunate that majority of the teachers are still applying the old method of teaching, that is, teacher-centered method and rote learning, which makes it difficult for children to learn and retain what is learned and according to the arguments of Paulo Freire, learning has not taken place rather the system of education is infected and suffering from narration sickness known as "Banking Concept" (Freire, 1993). In spite of rise in technology access, Gray, Thomas, and Lewis (2010) study assert that technology is grossly under-utilized in institutions irrespective of learners' grades, particularly in low income countries (third worlds). The National Education Association (2008) opined that the challenges in really integrating educational apps into the curriculum are faced by even schools with access to enabling devices. This could be due to teachers not familiarity with the usage of these 
devices (e.g., mobile apps or not non access to them). If teachers were to be familiar with the use of mobile educational apps in classrooms, more topics can be covered, students can participate actively, assignment can be easily submitted and checked by the teacher, students' horizon can be widened and they can become more creative. This paper will research into the benefits of using mobile educational apps to foster work and play in classroom and help teachers, policy makers and educationist become more aware. The main objective of the study is to find out the use of mobile educational applications to foster work and play in classroom. Other specific objectives are: i) To ascertain how mobile educational applications foster work and play in classroom; ii) To find out the effects of mobile educational applications on teaching and learning outcomes when used for work and play in classroom; and iii) To find out challenges confronting the usage of mobile educational apps in classroom. The research questions are as follows: i) How do mobile educational applications foster work and play in classroom?; ii) What are the effects of mobile educational applications on teaching and learning outcomes when used for work and play in classroom?; and iii) What are the challenges confronting the usage of mobile educational apps in classroom? The paper is organized thus: section one which is introduction covered background of the study, research objectives, research questions and the organization of the paper. Section two dealt with review of related literature. Section three presented the methodology (procedure) used in carrying out the research. Section four dealt with data analysis, results and discussion. Finally, section five dealt with conclusion, summary recommendations, limitation of the study and future work.

\section{Review of Related Literature}

Recently, many researchers have focused on mobile learning and its environment (Blackwell, 2014), compared to the former mode of teaching and learning that involves more of rote learning and teacher-centeredness. John Dewey in his educational theory expressed that one of the task of a teacher is to perform a complete rework, a complete organization, a true revolution of the old school from bookish school into a social school, a life that involves learning through what you can see and touch around you (Spaseva, 2016). Jean Piaget and Lev Semionovich Vygotsky were both enormously significant contributors to the cognitive development of children saying that the way children learn and mentally grow plays a central role in their learning processes and abilities (Brandi, 2011). By understanding the progression of cognitive development teachers enable themselves to better cater for the unique needs of each child by engaging them in both work (Hussein et al., 2019, Hussain et al., 2019; Hussain \& Mkpojiogu, 2017; Hussain et al., 2017; Hussain et al., 2016) and play (Brandi, 2011). Games and different plays can be used to teach and introduce different concept, as children are having fun so also are they learning and the concept becomes clearer and concrete (Malone \& Lepper, 1987). Music, animation and multimedia tools when used effectively can facilitate fun, game and play in classroom learning, making teaching more effective, efficient, interesting and pleasurable 
(Malone \& Lepper, 1987). Also, Quinn (1994) advocates and stresses the integration of fun (e.g., games) into the design of instructions and learning so as to profit and enhance learning. This integration will motivate interactivity and sociability in learning. Mobile Apps popularity in education field has contributed to this new learning style, use of smart phones, tablets and other mobile educational apps helps to foster work and play in classroom (Zhang \& Liao, 2015; Hussain et al., 2020c). According to Lepper and Cordova (1992) learning that involves fun or that incorporates play seems to be more successful, effective, and efficient in fostering work and play in classroom. Play and work can be facilitated by several ways with the use of interactive educational technologies. For instance, Ofcom (2017) observed that $10 \%$ of children within the ages 3-4 play online games, which demonstrates that online gaming can be attractive in learning (Plowman et al., 2012). Interactive educational artifacts are stimulants for imaginative and immersive play (Marsh, 2014; Mkpojiogu et al., 2020c; 2020d). The encourage autonomous and self-learning drive.

Obviously, younger learners enjoy and appreciate playing with digital toys with educational contents. Playing with learning applications opens the door and provides the basis for the development of learners' reasoning faculties and improved daily their critical, cognitive, social, behavioral and affective skills and knowledge (UNICEF, 2018). By the medium of play, young learners absorb the quality of connecting with other learners in a social setting and imbibe self-advocacy skills. They also learn to share, relate, negotiate, tolerate with others and resolve conflicts (UNICEF, 2018). In addition, they learn leadership and group skills through the avenue of play. Besides, play as a natural tool enable young people to learn coping and resilience skills. Through it they learn how to deal with challenging social issues and to navigate relationships and surmount their fears (UNICEF, 2018). In line with this, Malone and Lepper (1987) studied those elements that support fun and education in games. A number of multi-media effects facilitate this: audio, dynamic icons, videos, expressive elements, music, and other interactive capacities enable the evocation of sensory adventure and curiosity in learners in their use of interactive mobile platforms (Liu, Toprac, \& Yuen, 2009). There are several apps designed for education and learning (Demuynck \& Laureys, 2002). Surfing e-stores (e.g., Google Play Store for Android Apps) shows a diversity of learning applications for on several subjects. The integration of communication and information technologies, into educational processes have uncovered some essential ways to develop learner's cognition and episteme. The usage of innovative learning technologies galvanizes and fascinates the interest of learners in learning. Hence, the integration of these technologies in and out of the classroom is advocated is prior studies (Ferreira, Moreira, Pereira \& Durao, 2015). Interestingly, Kenney (2011) states that the ubiquitous presence of technology in the daily lives of learners makes classroom learning without it totally uninteresting. In addition, teacher/student bonds and relations is also promoted with the use of these technologies especially as the teachers get closely involved with the students. Also, these technologies promote their social learning as they support interaction among learners. This enables collaborative learning and makes learning more active (Ciampa, 2014; Hussain et al., 2020a; 2020b). Independence and sociality stimulated 
through learning apps awakens the instinct of independence and the social trait in learners which very natural.

There are a number of applications that support work and play in learning. These apps enable interactive, and immersive learning engagement and experience for learners outside the four walls of the formal classroom. The apps motivate and foster virtual self-directed and independent learning. Some of the applications in this category are: NOVA Elements, Bobo Explores Light, Project Noah, Brain POP Featured Movie, and Proloquo2Go, etc. Theses apps support customized and personalized authentic learning activities and foster collaborative learning among learners (Apple Inc., 2013; Mkpojiogu et al., 2020a; 2020b). The personalized quality of these apps spur individuation in learners.

\subsection{Benefits of Using Mobile Educational Apps in Classrooms}

Collaborative Teaching: Teachers can use a cell phone alone or with some special apps to make a video or voice call with an expert in order to achieve certain objectives in the classroom, prepare their lessons before teaching, record lesson through screencast-o-matic or camtasia and send to students to watch and the students can use it also in a group work. Assessment can be delivered via phone and learners can also engage socially using educational apps, sharing knowledge in a mutually beneficial, collaborative digital environment. Also, educators can use 'gamification' which makes lessons more engaging by using gaming principles in design alongside with mobile devices (Niall, 2016).

Learning Experiences: Mobile apps have the ability to transform the educational experience of students by given them opportunity to explore, do their homework and classwork. Mobile apps also allow teachers to enjoy greater convenience in the classroom by helping them stay organized, prepare their lesson, manage the classroom and teach efficiently (Lee, 2017).

Novel Learning Methods: The ushering in of educational apps has given rise to the introducing of novel methods of learning which is more students centered. These mobile apps include fun supporting games that indulge and stimulate students into a healthy cognitive process. It spurs adventure, curiosity and new discoveries and also help learners to understand and perceive things from different viewpoints (Roy, 2017).

Improved Educator/Parent Communications: Applications for educator/parent communication apps support the development of educator/parent bonding even outside the school environments (Roy, 2017). These relations enable educators to respond to the inquiries from parents about the progress of their wards. In addition, this facilitates the upholding of a transparent culture in the educational segment. Also, parents and teachers can now work collaboratively to help improve the child's academic performance and preparation for their future career. Schools do not need to wait for Parent-Teachers Association meetings to deliberate and decide on urgent issues, rather they communicate easily on the apps which cut cost, which are more reliable and time saving (Roy, 2017) 
Online Study and E-Books: Because of the attractiveness and independence in online studies, learners usually are fond of it (Roy, 2017). The innovative library applications and electronic books together with e-readers are fascinating to online learners. The ease of use of the apps enable learners to obtain suitable learning materials with the use of their mobiles anytime and anywhere. These apps facilitate learners' immersive participation in learning. It helps student discover lots of information on their own while supporting them in doing assignment and projects independently (Roy, 2017).

\subsection{Challenges Facing the Use of Mobile Educational Apps in developing countries}

Irregularities in power supply: Many developing countries could not still boast of regular power supply and people use more electricity generating set than they use electricity from the main power grid which makes it difficult for both teachers and students to use educational apps comfortably in classroom teaching and learning. Mobile gadgets need electricity, need to be charged and ready for use but if you lack what to use in charging your gadgets, how do you use them. This can pose difficulty for institutions to embark on using mobile educational apps in classroom for the fostering of play and work (Niall, 2016).

Availability of funds to purchase the required gadgets for school use: Some of the developing countries are not buoyant enough to purchase mobile devices and put them at the disposal of all students (Zhang \& Liao, 2015). For example, sometimes policies are made, funds are released to carry out the project but due to misappropriation of funds, projects die a natural death after few years of kicking off. Some individuals at the realm of affairs do not still believe in the provision of common amenities to reach every corner of the country in order for the poor masses to benefit from education schemes. However, these few in the helm of affairs rather divert the funds for something else other than improving the educational sector by including in the curriculum the use of mobile educational apps to foster work and play in all schools (Oladiji, 2018).

Paucity of teachers who knows how to use these apps effectively: The curriculum design for teacher training, lack courses on how teachers can use mobile educational apps to enhance teaching and learning in classroom (Fatunde, 2018). Lots of courses are taught in theory but the practical aspects are not being followed up. Most of the third world countries suffered the same faith, lacking technical knowledge and how to use apps in classroom (AAI, 2015)

Connectivity, maintenance and technical support: Another problem facing third world country is problem of connectivity and technicians who know much about the connections and how to install the devices (Mehdipour \& Zerehkafi, 2013). This makes connection to internet server's difficult, maintenance challenging and technical support inadequate. For example, in some remote villages, network services are still fluctuating and unstable. Some school does not have access to internet facility and finds it difficult to talk about buying or using educational devices (Agbakwuru, 2017). 
Negative social attitudes towards the use of mobile phones: Some people still believe in the traditional ways of teaching and hold on to it as the best. This group of people see mobile phones as disruptive devices that students use primarily to play games, chat with friends and potentially engage in inappropriate behaviors such as cheating, flirting, watching pornographic films, indulging in crimes, joining cult groups and cyber-bullying to mention but few. This makes it difficult for school to embrace the use of mobile educational apps to help foster work and play in schools (Agbakwuru, 2017).

\section{Methodology}

In order to explore the use of mobile educational apps to foster work and play in classroom teaching and learning, this paper employed a systematic literature review method in searching for appropriate conference proceedings, journal articles, and other related and relevant literatures. The activities involved in the systematic review exercise included: 1) first stage: the review planning, while 2) second stage: the conducting of the review, and then, 3 ) the final stage: the result presentation.

Review Planning: The goal of this stage is to collect vital and relevant information that are connected to how mobile educational apps can be used to foster work and play in learning. With respect to this, primary search involves the search and selection strategy. This primary search was done utilizing high impact journal articles and conference proceedings from online databases in the area of the use of mobile educational apps in fostering work and play in the classroom. In this study, search was done by employing the search strings: "Using mobile educational apps to foster work and play in the classroom". The review covered studies ranging from year 2000 to 2018. This ensured currency of information connected to mobile educational apps that can be used to foster work and play in classroom. Literatures, articles and conferences on mobile educational apps to foster work and play in classroom were limited. In Table 1 below the selected journal articles, and conferences proceedings are described.

Table 1. Selected Journals, articles and Conference Proceedings

\begin{tabular}{|l|l|}
\hline \multicolumn{1}{|c|}{ Selected Journals } & \multicolumn{1}{c|}{ Selected Conference proceedings } \\
\hline Journal of Education Research & $\begin{array}{l}\text { Proceedings of the } 5^{\text {th }} \text { International Conference on } \\
\text { Text, Speech and Dialogue, Czech Republic }\end{array}$ \\
\hline Journal of Research on Technology in Education & Proceedings of ICERI conference. Seville, Spain \\
\hline $\begin{array}{l}\text { The Turkish Online Journal of educational } \\
\text { Technology }\end{array}$ & Use of mobile apps for teaching and research \\
\hline $\begin{array}{l}\text { International Journal of Computational Engineering } \\
\text { Research }\end{array}$ & $\begin{array}{l}45^{\text {th }} \text { Hawaii International Conference on System } \\
\text { Sciences }\end{array}$ \\
\hline British Journal of Educational Technology & \\
\hline Journal of Computer Assisted Learning & \\
\hline Contemporary Educational Technology & \\
\hline Journal of Education and Practice & \\
\hline
\end{tabular}


Table 2. Number of articles/papers per journal/conference proceedings

\begin{tabular}{|c|c|}
\hline Journal, Conference Proceeding & No. of Papers \\
\hline JER & 3 \\
\hline JRTIE & 1 \\
\hline TOJET & 2 \\
\hline BJET & 2 \\
\hline IJCER & 3 \\
\hline JCAL & 1 \\
\hline CET & 2 \\
\hline JEP & 1 \\
\hline ICTSD & 2 \\
\hline ICERI & 3 \\
\hline UMATR & 2 \\
\hline EEASAE & 1 \\
\hline HICSS & 2 \\
\hline TOTAL & 25 \\
\hline
\end{tabular}

The articles chosen for this review anchored purposely on the use of mobile educational apps to foster work and play in classroom, its benefits and challenges facing the use of mobile educational apps. The following keywords were used in the review: mobile apps, educational apps, benefits, classroom learning, education, use of mobile apps. Also, all relevant articles were prudently chosen to extract the needed data for the review (see Table 2). The number of articles/papers chosen per conference proceedings or journal with a range of 1 to 3 are shown in Table 2 .

Review Conducting: this stage explains the way the review was conducted. In this stage, the search string, and the abstract of each downloaded article were carefully read assess their relatedness and relevance to the review study. Fifty studies were downloaded from conference proceedings and journals. Nevertheless, the papers chosen for further reading were the ones that has important contributions, so, just 35 papers were considered, out of which only 25 papers were eventually selected, carefully read, and examined for appropriate details that relate to the purpose of the review. Appropriate information (associated to using mobile educational apps to foster work and play in classroom, its benefits and challenges, were mined, and collated. It was based on this that the analysis shown in the results' section was done. Table 2 indicates the number of articles/papers chosen per and conference proceeding and journal. The chosen journals and conference proceedings, out of which the articles/papers were extracted are reputable. The complete list of chosen articles/papers are indicated in Table 3. These chosen articles/papers were from year: 2000 to 2018. The chosen articles offered a good representation of the studies within the period on the use, benefits and challenges of mobile educational apps. 
Table 3. List of chosen articles/papers

\begin{tabular}{|c|c|c|}
\hline Article ID & Authors & Year \\
\hline MEA 1 & Ally, M. et al. & 2014 \\
\hline MEA 2 & Blackwell, C. & 2014 \\
\hline MEA 3 & Courtney, B. & 2014 \\
\hline MEA 4 & Dornyei, Z. & 2000 \\
\hline MEA 5 & Demuynck, K. et al. & 2002 \\
\hline MEA 6 & Ertmer, P. A. et al. & 2010 \\
\hline MEA 7 & Ertmer, P. A. et al. & 2012 \\
\hline MEA 8 & Ferreira, M. J. et al. & 2015 \\
\hline MEA 9 & Gray, L. et al. & 2010 \\
\hline MEA 10 & Henderson, S. et al. & 2012 \\
\hline MEA 11 & Hinze, A. et al. & 2017 \\
\hline MEA 12 & Kenney, L. & 2011 \\
\hline MEA 13 & Lopuch, M. & 2013 \\
\hline MEA 14 & Maha, A. et al. & 2015 \\
\hline MEA 15 & Mehdipour, Y. et al. & 2013 \\
\hline MEA 16 & Niall, M. & 2016 \\
\hline MEA 17 & Pachler, N. et al. & 2011 \\
\hline MEA 18 & Ross, S. M. et al. & 2010 \\
\hline MEA 19 & Shrivastava, M. et al. & 2014 \\
\hline MEA 20 & Shuler, C. & 2009 \\
\hline MEA 21 & Singh, M. & 2010 \\
\hline MEA 22 & West, D. M. & 2013 \\
\hline MEA 23 & Watlington, D. & 2011 \\
\hline MEA 24 & Wong, C.Y. et al & 2010 \\
\hline MEA 25 & Zhang, J. et al. & 2015 \\
\hline
\end{tabular}

Several online databases were utilized to facilitate this study. They are: Academia, Google Scholar, and ResearchGate. In these 3 online databases, a sum of fifty (50) articles/papers were discovered out of which twenty-five (25) were eventually chosen for the study. The different online database accessed and the total sum of papers discovered and chosen are shown in Table 4.

Table 4. Online databases and Chosen papers

\begin{tabular}{|l|c|c|}
\hline \multicolumn{1}{|c|}{ Online Databases } & Papers Found & Papers Chosen \\
\hline Google Scholar & 25 & 16 \\
\hline Research Gate & 15 & 3 \\
\hline Academia.Edu & 10 & 25 \\
\hline Total & 50 & \\
\hline
\end{tabular}


Inclusive and Exclusive Criteria: to establish the delimitation of this study, some exclusion conditions were used to eliminate the aspects that are not within the scope of the study. In like manner, some inclusive criteria were set scope the study. 1) Exclusive criteria: the following were eliminated from the search and review: the design of mobile communications, tools for mobile communications, and online learning environment enhancement and motivation frameworks. These were omitted from the research because they and were out of the scope the review. 2) Inclusive Criteria: The following conditions were included in the search and review: all aspects of mobile educational apps in fostering work and play in classroom together with some mobile apps used to foster work and play in classroom, benefits of using mobile educational apps in classroom and the challenges confronting the usage of mobile educational apps.

\section{Results}

The review results on the use of mobile educational apps to foster work and play in learning, the benefits of using such apps and the challenges facing its use are presented in this section. The percentages of research papers in the area of mobile educational apps used to foster learning in a work and play scenario, the benefits of using such apps and the challenges facing the use of the apps are indicated below.

Table 5. Mobile apps use to foster work and play in classroom

\begin{tabular}{|l|c|c|}
\hline $\begin{array}{c}\text { Mobile apps use to foster work/play in } \\
\text { classroom }\end{array}$ & Frequencies of studies & Percentage \\
\hline Nova Elements & 3 & $12 \%$ \\
\hline Bobo Explores Light & 2 & $8 \%$ \\
\hline Project Noah & 3 & $12 \%$ \\
\hline Brain POP Featured Movie & 4 & $16 \%$ \\
\hline Proloquo2Go & 3 & $12 \%$ \\
\hline
\end{tabular}

Table 5 shows the findings gotten from the chosen and reviewed articles. This findings indicate that the review elicited a number of mobile applications used in classroom with regards to the Nova elements app (12\%), Bobo explore light app (8\%), Project Noah app (12\%), Brain POP featured movie app (16\%), and Proloquo2Go (12\%).

Table 6. Benefits of using mobile educational apps in classroom

\begin{tabular}{|l|c|c|}
\hline \multicolumn{1}{|c|}{ Benefits } & Frequencies & Percentage \\
\hline Collaborative Teaching & 5 & $20 \%$ \\
\hline Learning Experience & 5 & $20 \%$ \\
\hline New Learning Method & 5 & $20 \%$ \\
\hline Enhanced parent/ Teacher Communication & 5 & $20 \%$ \\
\hline E-Books and Online Study & 5 & $20 \%$ \\
\hline
\end{tabular}


Table 6 reveals the benefits of mobile educational apps in fostering work and play in classroom, showing collaborative teaching $20 \%$, learning experience $20 \%$, new learning method 20\%, enhanced parent/teacher communication $20 \%$ and EBook/online study $20 \%$.

Table 7. Challenges facing the use of mobile educational apps

\begin{tabular}{|l|c|c|}
\hline \multicolumn{1}{|c|}{ Challenges } & Frequencies of studies & Percentage \\
\hline Irregularities in power supply & 3 & $12 \%$ \\
\hline Availability of funds & 3 & $12 \%$ \\
\hline Paucity of Teachers & 2 & $8 \%$ \\
\hline Connectivity/maintenance/technical support & 1 & $4 \%$ \\
\hline Negative social attitudes & 1 & $4 \%$ \\
\hline
\end{tabular}

In Table 7 above, the reviewed articles revealed some of the challenges facing the use of mobile educational apps in classroom like, irregularities in power supply $12 \%$, availability of funds $12 \%$, paucity of teachers $8 \%$, connectivity/maintenance/technical support $4 \%$ and negative social attitudes $4 \%$.

\section{$5 \quad$ Discussion of Findings}

The results show that much has to be done in incorporating the use of mobile educational apps in fostering work and play in learning in most part of developing world. This also affects the area of challenges facing the use of mobile educational apps as regards to third world countries. Niall (2016) assert that the lowing in the cost of mobile devices along with the blossoming in the development of educational apps implies that several learners in emerging economies can now also access good media on education for out-of-classroom learning. The rise in mobile access particularly in third world countries will enable school administrators, policy makers, teachers and educationist take learning to students' who commute daily to school and homes. This improved access will make 'learning on the go' a suitable way to get a wider spectrum of learners who desire and possess the ability to learn but however, are restrained because of inability to undergo the traditional learning via the formal classroom education (Niall, 2016). The outcome of this review underscores and supports the work of Frobel, Montessori and Vygotsky (early childhood education proponents who advocated that children should be taught through play) as cited in Onukaogu et al. (2010).

\section{Conclusion}

Obviously, there are quite a number of literatures, journal articles and conference proceedings concerning mobile educational apps. This paper was aimed at reviewing literature sources on mobile educational apps in fostering work and play in learning. A systematic review of literature was utilized to achieve the study's objectives. 
Appropriate articles on the use of mobile educational apps to foster work and play in classroom were chosen using systematic literature review procedure. Of the fifty (50) articles downloaded, twenty-five (25) relevant ones used for the review. To obtain answers for the study's research questions, the chosen papers were pertinently read to obtain the required outcomes. The outcomes of the review reveals the following: there are different mobile educational apps designed to foster work and play in classroom teaching and learning. Hence, the results got from this study showed that mobile educational apps are used in classrooms and it has a lot of benefits. In addition to this, the research identified some issues confronting the usage of mobile educational apps in classroom especially in third world countries. The results from this paper provide additional knowledge for educators, curriculum planners, policy makers, teachers and students on the present state of practice and research on the use of mobile educational applications in fostering work and play in learning.

Sequel to the study's outcome, it is recommended that teachers, curriculum planners, policy makers, administrators and caregivers should be provided with knowledge on the new trend of mobile learning and its importance to education sector so as to square up and mitigate the issues faced by the use of mobile educational apps in third world countries and have more effective and efficient teaching. The paper though tries to look at mobile educational apps in fostering work and play in classroom, did not explore more on the existing mobile educational apps and research into how they can be used at all level to foster work and play in order to improve on learning and teaching in classroom setting. Further still, the fewness of the download also limited the results of the study. Further studies should be done looking at challenges raised and how it can affect students' academic performance and look into possible solutions especially focusing on incorporating the use of mobile educational apps to foster work and play in education system curriculum and teacher training curriculum in order to meet up with the demands of education in this century. It is necessary that more research on the use of mobile educational apps in third world country schools be carried out more regularly to elicit and fill further existing gaps and solve more related research problems. In comparison to advanced countries, the condition is very serious. Therefore, more efforts still need to be made to put things in place in third world schools. Future works will ensure that more downloads are made to enhance on the findings of the study.

\section{$7 \quad$ References}

[1] Ally, M. \& Tsinakos, A. (Eds.) (2014). Increasing access through mobile learning. Vancouver, BC: Commonwealth of Learning Press.

[2] Apple Inc. (2013). Apps in the classroom. USA: www.apple.com/itune/what-is

[3] AAI. (2015). State of education in Africa report: A report card on the progress, opportunities and challenges confronting the African education sector. New York: The Africa-America Institute.

[4] Agbakwuru, J. (2017). The state of education in Nigeria calls for a serious concern. Nigeria: Vanguard newspaper. www.vanguardngr.com 
[5] Blackwell, C. (2014). Teacher practices with mobile technology integrating tablet computers into the early childhood classroom. Journal of Education Research. Northwestern: Nova Science Publishers, Inc, 7(4), 1-25.

[6] Brandi, D. (2011). Piaget vs Vygotsky: The cognitive development theory. USA: Associated Content Publishers.

[7] Ciampa, K. (2014). Learning in a mobile age: an investigation of student motivation. Journal of Computer Assisted Learning, 30(2), 82-96. Canada: John Wiley and Sons Ltd. https://doi.org/10.1111/jcal.12036

[8] Deci, E. L., \& Ryan, R. M. (1985). Intrinsic motivation and self-determination in human behavior. New York, NY: Plenum.

[9] Dornyei, Z. (2000). Motivation in action: Towards a process-oriented conceptualization of student motivation. British Journal of Educational Psychology, 70(4), 519-538. https://doi.org/10.1348/000709900158281

[10] Dosunmu, S. (2011). The need for value Re-orientation through enhancement of indigenous education in Nigeria .Lagos: Hoom- Bethakz Publishers.

[11] Demuynck, K., \& Laureys, T. (2002).A comparison of different approaches to automatic speech segmentation. Proceedings of the 5th International Conference on Text, Speech and Dialogue, Brno, Czech Republic, September 2002, pp. 277-284. https://doi.org/10.1007/3-540-46154-x 38

[12] Ertmer, P. A., Addison, P., Lane, M., Ross, E., \& Woods, D. (1999).Examining teachers' beliefs about the role of technology in the elementary classroom. Journal of Research on Computing In Education, 32(1), 54.

[13] Ertmer, P.A., \& Ottenbreit-Leftwich, A.T. (2010). Teacher Technology Change: How Knowledge, Confidence, Beliefs, and Culture Intersect. Journal of Research on Technology in Education, 42(3), 255-284. https://doi.org/10.1080/15391523.2010. 10782551

[14] Ertmer, P.A., Ottenbreit-Leftwich, A.T., Sadik, O., Sendurur, E., \& Sendurur, P. (2012). Teacher Beliefs and technology integration practices: A critical relationship. Computers \&Education, 59, 423-425. https://doi.org/10.1016/j.compedu.2012.02.001

[15] Freire, P. (1993). The banking concept of education.In pedagogy of the oppressed (Chapter 2). Retrieved from http://faculty. Webster.edu/corbetre/philosophy/education/Freire2.html.

[16] Ferreira, M. J., Moreira, F., Pereira, C. S., \& Durao, N. (2015). The role of mobile technologies in the teaching and learning process improvement in Portugal. Proceedings of ICERI Conference. Seville, Spain.

[17] Fatunde, T. (2018). Is Nigeria education system beyond redemption? Nigeria: Punch News app.

[18] Ghani, A.B.A., Kaliappen, N., Jermsittiparsert, K. (2019). Enhancing Malaysian SME Employee Work Engagement: The Mediating Role Of Job Crafting In The Presence Of Task Complexity, Self-Efficacy And Autonomy. International Journal of Innovation, Creativity and Change, 6 (11), pp. 1-18.

[19] Gray, L., Thomas, M., \& Lewis, L. (2010).Teachers' use of educational technology in US public Schools: 2009 (NCES 2010-040). Washington, DC: National Center for Education Statistics, Institute for Education Sciences, U.S. Department of Education. Retrieved from: http://nces.ed.gov/pubs2010/2010040.pdf . https://doi.org/10.1037/e492162006-002

[20] Henderson, S., \& Yeow, J. (2012). iPad in Education: A case study of iPad adoption and use in primary school. Proceedings from HICSS, 2012: The 45th Hawaii International Conference on System Sciences. Manoa, HI. https://doi.org/10.1109/hicss.2012.390 
[21] Hinze, A., Vanderschantz, N., Timpany, C., Cunningham, S. J., Saravani, S. J., \& Wilkinson, C. (2017).Use of mobile apps for teaching and research. Working Paper: The University of Waikato. Hamilton, New Zealand. pp. 1-22.

[22] Hussein, I., Hussain, A., Mkpojiogu, E.O.C., \& Nathan, S.S. (2019). The state of user experience design practice in Malaysia. International Journal of Innovative Technology and Exploring Engineering, 8(8S), 491-497.

[23] Hussain, A., Hussein, I., Mkpojiogu, E.O.C., \& Sarlan, A. (2019). The state of user experience design (UXD) practice in Malaysia: an in-situ interview approach. International Journal of Innovative Technology and Exploring Engineering, 8(8S), 498505.

[24] Hussain, A., \& Mkpojiogu, E.O.C. (2017). Predicting the perceived worth of software products requirements with customer satisfaction. Advanced Science Letters. 23(5), 42694273. https://doi.org/10.1166/asl.2017.8245

[25] Hussain, A., Mkpojiogu, E.O.C., Muniandy, Y., Roslan, N.F.S, \& Aslam, M. (2020b). An Assessment of the Ergonomic Quality of a Mobile Cinema App with Novice and Expert Users. International Journal of Advanced Science and Technology (IJAST), 29(08), 172179.

[26] Hussain, A., Mkpojiogu, E.O.C., \& Nawi, M.N.M. (2017). Capturing customer satisfaction and dissatisfaction in software requirements elicitation for features in proposed software systems. Journal of Engineering and Applied Sciences (JEAS), 12(21), 5590-5597

[27] Hussain, A., Mkpojiogu, E.O.C., Wahab, R.B., Meh, N.H.C., \& Zaaba, Z.F. (2020c). Users' Perception on the Pragmatic Comfort of a Mobile eWallet Application. International Journal of Advanced Science and Technology (IJAST), 29(08), 188-193.

[28] Hussain, A., Mkpojiogu, E.O.C. \& Yusof, M.M (2016). Perceived usefulness, perceived ease of use, and perceived enjoyment as drivers for the user acceptance of interactive mobile maps. Proceedings of the $1^{\text {st }}$ International Conference on Applied Science and Technology (ICAST'16), Kedah, Malaysia. AIP Conf. Proc. 1761 (1). 020051, http://dx.doi.org/10.1063/1.4960891.

[29] Kenney, L. (2011). Elementary education, There's an App for That: communication technology in the elementary school classroom. Elon Journal of Undergraduate Research.

[30] Lee, S. (2017). Technology in the classroom: How schools are using app development to support education. London: Glance Creative Ltd.

[31] Lepper, M. R., \& Cordova, D. I. (1992). A desire to be taught: Instructional consequences of intrinsic motivation. Motivation\& Emotion, 16, 187-208. https://doi.org/10.1007/ bf00991651

[32] Liu, M., Toprac, P., \& Yuen, T. (2009). What factors make a multimedia learning environment engaging: A case study. In R. Zheng (Ed.), Cognitive effects of multimedia learning (pp. 173-192). Hershey, PA: Idea Group Inc. https://doi.org/10.4018/978-160566-158-2.ch010

[33] Lopuch, M. (2013). The effects of educational apps on student achievement and engagement. USA: eSpark Publishing Ltd.

[34] Malone, T.W., \& Lepper, M. R. (1987). Making learning fun: taxonomy of intrinsic motivations for learning. In R. E. Snow and M. J. Farr (Eds.), Aptitude, learning, and instruction: III. Conative and affective process analyses. 223-253. Hillsdale, NJ: Erlbaum.

[35] Maha, A., \& Mohammad, H. (2015). Mobile applications' impact on student performance and satisfaction. The Turkish Online Journal of Educational Technology, 14(4), 102-112.

[36] Marsh, J., Plowman, L., Yamada, D., Bishop, J., Lahmar, J., \& Scott, F. (2018). Play and creativity in young children's use of apps. British Journal of Educational Technology,49(5), 870-882. https://doi.org/10.1111/bjet.12622 
[37] Marsh, J. (2014). Online and offline play In Burn, A., Richards, C (Eds.), Children games in the new media age. Cambridge: Ashgate

[38] Mehdipour, Y., \& Zerehkafi, H. (2013). Mobile learning for education: Benefits and challenges. International Journal of Computational Engineering Research, 3(6), 93-95. www.ijceronline.com.

[39] Mkpojiogu, E.O.C., Akusu, G.E., Hussain, A., \& Hashim, W. (2020a). Eliciting and modeling the requirements for an online data archival management system. International Journal of Advanced Science and Technology (IJAST), 29(06), 296-306.

[40] Mkpojiogu, E.O.C., Akusu, G.E., Hussain, A., \& Hashim, W. (2020b). Implementation of a web-based data archival management system. International Journal of Advanced Science and Technology (IJAST), 29(06), 307-319.

[41] Mkpojiogu, E.O.C., Sherriff, G., Hussain, A., \& Hashim, W. (2020c). Comparing the performance of Players Unknown Battle Ground (PUBG) mobile app on iPhone X and Samsung S9 Plus smartphones. International Journal of Advanced Science and Technology (IJAST), 29(06), 320-325.

[42] Mkpojiogu, E.O.C., Akusu, G.E., Hussain, A., Kamal, F.M., \& Lim, C.K. (2020d). Comparing the Quality of Service Performance of Iphone X and Samsung S9 Plus Smartphones with WhatsApp Messenger. International Journal of Advanced Science and Technology (IJAST), 29(08), 194-200.

[43] National Education Association. (2008). Access, Adequacy, and Equity in Education Technology: Results of a Survey of America's Teachers and Support Professionals on Technology in Public Schools and Classrooms. Washington, DC.

[44] Niall, M. (2016).Mobile learning in Africa: How mobile education technology benefits learners. South Africa: Word press.

[45] Oladiji, T. (2018). Is Nigeria education system beyond redemption. Nigeria: Punch News app.

[46] Onukaogu, C. E.; Oyinloye, G. O. \& Iroegbu. V. I. (2010). A capacity enhancement workshop training manual for early child care and development education teachers. IkejiArakeji: JABU.

[47] Ofcom. (2017). Children and parents: Media use and attitudes report. London: Ofcom https://www.ofcom.org.uk

[48] Pachler, N., Pimmer, C., \& Seipold, J. (2011). Work-based mobile learning: concept and cases. A handbook for evidence-based practice. Oxford, Bern, Berlin, Bruxelles, Frankfurt am Main, New York, Wien: Peter-Lang. https://doi.org/10.3726/978-3-0353-0496-1

[49] Pinkwart, N. (2003). Educational scenarios for cooperative use of Personal Digital Assistants. Journal of Computer Assisted Learning, 19(3), 383-391. https://doi.org/10.10 46/j.0266-4909.2003.00039.x

[50] Plowman, L., Stevenson, O., Stephen, C., \& Mcpake, J. (2012). Preschool children's learning with technology at home. British Journal of Educational Technology, 49(5), 870882. https://doi.org/10.1016/j.compedu.2011.11.014

[51] Quinn, C. N. (1994). Designing educational computer games. In K. Beattie, C. McNaught, and S. Wills (Eds.), Interactive multimedia in university education: Designing for change in teaching and learning, 45-57. Netherland: Elsevier.

[52] Ross, S. M., Morrison, G. R., \& Lowther, D. L. (2010). Educational technology research past and present: Balancing rigor and relevance to impact school learning. Contemporary Educational Technology, 1(1), 19. https://doi.org/10.30935/cedtech/5959

[53] Shrivastava, M., \& Shrivastava, S. (2014).Political economy of higher education: Comparing South Africa to trends in the World. High Educ. 67, pp. 809-822. https://doi.org/10.1007/s10734-013-9709-6 
[54] Sheingold, K. (1991). Restructuring for learning with technology: The potential for synergy. Phi Delta Kappan, 73(1), 17-27.

[55] Singh, M. (2010). "M-Learning: A New Approach to Learn Better". International Journal of Education and Allied Sciences, 2(2), 65-72.

[56] Shuler, C. (2009). Pockets of potential: Using mobile technologies to promote children's learning. New York, NY: The Joan Ganz Cooney Center at Sesame Workshop.

[57] Spaseva, S. (2016). The educational theory of John Dewey and its influence on educational policy and practice in Macedonia. Espacio, Tiempo y Educacion, 3(2), 207-224. https://doi.org/10.14516/ete.2016.003.002.009

[58] Unicef. (2018). Learning through play. New York: www.unicef.org/publication

[59] Wartella, E., \& Jennings, N. (2000).Children and Computers: New Technology-Old Concerns. The Future of Children, 10(2), 31-43. https://doi.org/10.2307/1602688

[60] Watlington, D. (2011). Using iPod touch and ipad educational apps in the classroom. In Society for Information Technology and Teacher Education International Conference, 2011(1), pp. 3112-3114.

[61] West, D. M. (2013). Mobile Learning: Transforming education, engaging students and improving outcomes in Brookings Policy Report.

[62] Wong, C. Y., Chu, K., Khong, C. W., \& Lim, T. Y. (2010). Evaluating playability on haptic user interface for mobile gaming. Paper presented at the Information Technology International Symposium, 15-17 June, Kuala Lumpur, Malaysia. https://doi.org/10.1109/ itsim.2010.5561513

[63] Zhang, J., \& Liao, B. (2015). Learning on the fingertips: The opportunities and challenges of educational apps. Journal of Education and Practice, 6(20), 62-67. Retrieved from:www.iiste.org

[64] Nuur Wachid Abdul Majid, Syifaul Fuada. (2020). E-Learning for Society: A Great Potential to Implement Education for All (EFA) Movement in Indonesia. International Journal of Interactive Mobile Technologies, 14(2), 250-258. https://doi.org/10.3991/ ijim.v14i02.11363

[65] Che Ghani Che Kob, Shangeetavaani Kannapiran, A. Shah. (2020). The Usage of Mobile Learning: Comparative Studies among Technical and Vocational Education Students in Selected Universities. International Journal of Interactive Mobile Technologies, 14(5), 203-209. https://doi.org/10.3991/ijim.v14i05.13355

[66] Valerie Bukas Marcus, Noor Azean Atan, Sanitah Mohd Yusof, Lokman Tahir. (2020). A Systematic Review of e-Service Learning in Higher Education. International Journal of Interactive Mobile Technologies, 14(6), 4-14. https://doi.org/10.3991/ijim.v14i06.13395

\section{Authors}

Azham Hussain is the Associate Professor of Software Engineering at School of Computing, Universiti Utara Malaysia, Kedah, Malaysia. He is the founder of Human-Centered Computing Research Group, which is affiliated with the Software Technology Research Platform Center at School of Computing, Universiti Utara Malaysia. Azham Hussain is a member of the US-based Institute of Electrical and Electronic Engineers (IEEE), and actively involved in both IEEE Communications and IEEE Computer societies. 
Emmanuel O.C. Mkpojiogu is a Lecturer at Department of Computer and Information Technology, Veritas University, Abuja, Nigeria. Currently, he is a $\mathrm{PhD}$ student at School of Computing, Universiti Utara Malaysia. The research area is User Experience, Human Computer Interaction and Software Engineering. He has published many articles in reputable Scopus indexed journals. emelnuel@gmail.com

Elizabeth Tolulope Babalola is a student at the Department of Educational Foundations, Veritas University, Abuja, Nigeria. She is an upcoming researcher in Psychology with a number of articles in Counseling Psychology. Email: lizzybabalola@yahoo.com

Article submitted 2020-06-26. Resubmitted 2020-07-25. Final acceptance 2020-07-25. Final version published as submitted by the authors. 